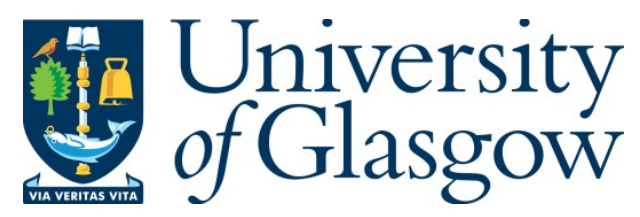

Armstrong, S., Blaustein, J., and Henry, A. (2016) Impact and the reflexive imperative in criminal justice policy, practice and research. In: Armstrong, S., Blaustein, J. and Henry, A. (eds.) Reflexivity and Criminal Justice: Intersections of Policy, Practice and Research. Palgrave Macmillan: Basingstoke, pp. 1-30. ISBN 9781137546418

There may be differences between this version and the published version. You are advised to consult the publisher's version if you wish to cite from it.

http://eprints.gla.ac.uk/134493/

Deposited on: 23 January 2017

Enlighten - Research publications by members of the University of Glasgow http://eprints.gla.ac.uk 


\section{Chapter 1 Impact and the reflexive imperative in criminal justice policy, practice and} research

Sarah Armstrong (University of Glasgow), Jarrett Blaustein (Monash University) and Alistair Henry (University of Edinburgh)

Abstract: This chapter is a substantive editorial introduction to the book, Reflexivity and Criminal Justice: Intersections of Policy, Practice and Research. It develops and argues for an account of reflexivity in criminology beyond the researcher-researched relationship to the field of research itself. Universities are under increasing pressure to document the value of their work, often defined instrumentally in terms of immediate practical and commercial activities. This has led to increasing emphasis on 'partnerships' and knowledge exchange with organisations and actors outside of academia. While such relationships may be empowering and supportive of good research, they also raise critical questions about agenda setting and valuation of social science. These questions become especially acute in a discipline such as criminology, with its attention to crime control, surveillance and state punishment, topics which can be co-opted by particular interests. We address the potential and risks of reflexivity in this setting, concluding that it might offer a stance that assists researchers in exposing the complicated dynamics of the conditions of criminal justice research in contemporary times. The content of the chapters which comprise the book are summarised and woven into the discussion throughout this introduction.

This volume grows out of two parallel but distinct developments in social science research that affect the way researchers study and seek to have an impact in the areas of crime and criminal justice. These are the increasing acceptance and practice of (some form of) reflexivity in social science research, one the one hand, and on the other, the changing context of research itself. On the latter point, we note that criminologists working across different jurisdictions are experiencing heightened pressures to render their research relevant and appealing to external audiences. These pressures are linked in part with the fact that governments in Australia, the United Kingdom and the United States (along with other countries) are increasingly keen to ensure that their investment in the higher education sector is delivering 'value for money'. This implies that research and teaching activities that are government-funded must increasingly align with, or at least demonstrate alignment with, what these governments define as the public interest. In Australia, for example, the Australian Research Council, which is responsible for administering public research funding, has identified a list of nine strategic 'Science and Research Priorities' to organise funding of 'support for science and research on the most important challenges facing Australia' (developed partly from a 2014 white paper 'Boosting the commercial returns of research'; see ARC 2016). With the possible exception of 'cybersecurity', none of these strategic priorities appear to be directly relevant to criminology or indeed, the social sciences.

The specified research priorities relate primarily to what are known as 'STEM' subjects (Science, Technology, Engineering and Medicine), thereby prioritizing an increasingly narrow set of 
subjects and research methodologies that reflect a pragmatic and in our view myopic governmental understanding of what constitutes societal value.

This growing emphasis on pragmatism further implies that universities as the institutional sites within which much of what constitutes criminological research today takes place are also expected to operate efficiently. Notions of accountability, and more specifically financial accountability (Power 1999), thus constitute powerful discursive mechanisms that ultimately contribute to the legitimation of an overarching programme of public divestment from the higher education sector. Politicians are prone to justifying these cuts by invoking the language of austerity. Some academics have come to associate contemporary discourses of austerity with a wider neoliberal project, one that is generally cited as a threat to the future of the sector and the pursuit of independent academic inquiry. A recent and influential paper notes that the high productivity and compressed time frames of the 'neoliberal university' create isolating and divisive work conditions, further undermining critical and independent research agendas (Mountz et al. 2015).

No longer able to rely primarily on government investment as a primary source of research income, universities have also started placing greater emphasis on the need for academics to assume the role of research entrepreneurs. The STEM subjects are perhaps ideally placed to develop lucrative partnerships with industry, but the social sciences are not immune to this development. Researchers from all disciplines are facing pressures to market their work to prospective research partners (read: funders) as well as users spanning the public, private and third sectors. Many academic criminologists along with their counterparts from other disciplines have vocally opposed these managerial pressures and expressed concerns about the implications of research commodification with respect to academic autonomy. For criminologists, the preservation of academic autonomy is especially crucial due to the discipline's historical legacy as a technology of governmental control (Foucault 1980) and our recognition of the risk that policy makers and practitioners may utilise our concepts, data and theoretical constructs to justify coercive practices or unjust policies, impinge upon the rights and freedoms of vulnerable individuals and groups, and potentially even generate harms (Cohen 1988). The intersections that exist between criminological research, policy and practice might therefore be characterised as ethical minefields.

Ironically, while the political and institutional environment in which research takes place is 
becoming more instrumental and less well funded, criminology as a discipline is flourishing. This is evident from the growth of undergraduate and postgraduate degree programmes and jobs across Europe and North America. Our sense is that this is due, at least in part, to the field's relative strength in arguing for its own relevance and importance given the perennial policy fixation on questions of crime and security in these regions. Of course, this is not to take away from the excellence of much criminological research. Indeed, what has been particularly marked in the past twenty years has been the field's enriching pluralism and the ability to support so many research traditions and perspectives (Loader and Sparks 2011; Bosworth and Hoyle 2011). While some criminologists have characterised this trend as disciplinary fragmentation, broken into 'independent', 'critical' and 'administrative' schisms (Young 1986; Ericson and Carriere 1994; Hough 2014), we tend to side with commentators who see pluralisation as a process of mutual enrichment because it implies that criminology is no longer, if it ever truly were, tied to its originating thinkers and disciplinary influences. Criminologists today not only draw on the methods of, but also have important things to say to and are taken seriously by, historians, sociologists, geographers, philosophers, political scientists, economists, cultural theorists and more.

In addition to looking outward for inspiration, criminologists increasingly are looking inward, critically and reflexively scrutinising their own field and the research that is produced through it. While there remains in some corners an impulse toward particular strands of scientific (and particularly medicalised or psychologised) methods and models, like the experiment (of which even medical researchers are increasingly critical and sceptical), post-positivist, reflexive engagement has become ever more of an explicit topic as recent criminological texts attest (see for example, Lumsden and Winter 2014; Bosworth and Hoyle 2011). It is our contention then that the concept of reflexivity provides a valuable resource for navigating the practical and ethical dilemmas posed by our changing research environment. And in this, we believe the volume offers a new and important contribution for thinking about reflexivity and its potential to illuminate the nature of the social, of which researchers, universities, policy processes and makers are a part. Specifically, all the contributors to this book are grappling in different ways not only with how to employ notions of research in particular projects but with how we might engage wider political, economic and social contexts of the worlds that both researcher and researched occupy. Criminal justice and academic settings are increasingly governed through the same technologies of measurement and performance - how do we begin to document, analyse and make sense of this? We argue that criminologists must be sensitive to how structural and cultural 
conditions within the higher education sector have come to influence the questions we seek to explore and the methods and collaborative research partnerships we draw upon to do so. Hence reflexivity is conceived in this book as more than a way of approaching the encounter of researcher and researched, but also, as our subtitle states, also a way of centring and exploring the intersection of policy, practice and research.

In this chapter, we set out some of the dynamics in the research environment that require us to think through and expand upon ideas of reflexivity as a problem not only for research, but for policy and practice in criminal justice. First, we discuss the current context of criminal justice research and review key aspects of the reflexivity concept as these have arisen in social science debates so far. We then present a re-worked notion of reflexivity, incorporating both its potential and its challenges, that can be employed to develop insights on the inter-connected areas of criminal justice research, policy and practice. Throughout our discussion we refer to the ways in which the contributors to this volume themselves are engaging the notion of reflexivity. Though each chapter provides its own examples of and stance towards reflexivity, this book overall makes the case for an expansion of a criminological agenda in which the processes, objects and actors often treated as 'backstage' to the analysis of crime and punishment join the conventional objects of anlaysis front and centre.

\section{The current context of criminal justice research}

Criminological research is inherently political because 'crime', its object of study, lacks a fixed reality. It is a social construction, the contours of which vary across time and jurisdiction, and which are in part shaped, validated or reconfigured by the work of criminologists, albeit not in isolation (Maguire 2012). Indeed the representations of crime and order made by political actors, criminal justice institutions, third sector and campaigning organisations and, of course, the mass media probably play a more crucial a role in framing public, and criminological, understandings of the 'crime problem' than does academic research. This implies that criminological research has never had anything approaching a monopoly over criminal justice discourse and 'crime talk' (Garland and Sparks 2000: 2-5).

Up until the 1970s, in the UK and the US at least, crime was largely viewed by political elites and parties as a technical administrative matter with, to contemporary eyes, surprising levels of party political consensus over its management (Loader 2006). However, from then on crime control came to play important roles in shaping both party political debate (Downes and Morgan 2012) 
and the very public sensibilities to which such debates speak (Garland 2000; Simon 2007). Crime and its control became increasingly salient in state claims to sovereignty and authority (Garland 1996), even eclipsing broader public service and welfare rationales for action, becoming the driver of policy initiatives in wider fields including education, family law, child welfare, and housing (Simon 2007; Crawford 1998). All of this meant that criminological research, where it even tried to engage with criminal justice policy and practice, tended to do so within a highly politicised, oft contested and thus notably emotional sphere of public policy, a sphere which, as already noted, was crowded with other powerful actors, vested interests and alternative representations. Many developments have taken place subsequently thus complicating and showing the evolution of this well-rehearsed history of the politics of crime control in the UK and the US. We focus on a few such developments here in order to sketch what we see as the main features of the current context within which criminological research gets done.

\section{Shifting grounds of concern}

Downes and Morgan (2012) argue that the days of intense partisan criminal justice politics may be on the wane, going as far as to suggest that the governing through crime agenda may currently be 'debased currency' (2012: 203). Perhaps in the aftermath of global recession, crime control has played a less decisive role in post-2008 elections and there is, for the moment, considerable agreement across political parties on key areas of criminal justice, in particular around 'volume crime' and its management through adaptive or 'dispersed' strategies that look beyond criminal justice institutions themselves for solutions (Downes and Morgan 2012: 183). Rather, they argue that much public debate about crime control in the UK (though one might consider the Black Lives Matter movement in the US in a similar vein) has coalesced around specific scandals, only some of which, such as the 2011 urban disorders in England, have really sparked the kinds of demonizing rhetoric that had characterised much crime talk in recent years (2012: 201-203). Whether this will present a more welcoming climate for deliberation around criminological research in the longer term remains to be seen (see, for example, Brown et al. 2015, writing critically about justice reinvestment as a model for penal reductionism). Also counter to this optimism, it might be argued that it is the terms and focus of contestation that have shifted (as well as multiplied, hybridised and pluralised) targets of othering and stigmatisation, and in the present moment it appears that migration flows and terrorism have emerged as potent rallying points for fear and reactionism. As Mary Bosworth and Blerina Kellezi note in their chapter to this volume, reactions against migration have produced an entirely new system of control and detention that should be of interest to criminologists. They narrate the emotional toll of these 
new forms of the carceral, not only on the confined but on the researcher as well, employing a reflexive lens to suggest how these sites cannot be equated simply with imprisonment, presenting distinct logistical, affective and intellectual challenges for researchers.

\section{Criminal justice policy research}

There are already quite extensive literatures on the various components of the criminal justice system. What has been rather less developed is research more explicitly focused on criminal justice policy itself: the actors involved, the roles of expert knowledge within it, and the processes through which it takes shape (Newburn and Sparks 2004). There are some notable exceptions (inter alia, the work of Paul Rock; Armstrong, 2010; Annison 2015; Blaustein 2015; Morrison and Sparks 2015; Souhami 2007; McAra 2005, 2016; Jones and Newburn 2002); however, the lack of attention to policy is becoming, particularly in the context of a research agenda premised on some notion of 'impact', an increasingly glaring lapse in criminological scholarship, a gap this volumes aims partly to fill.

\section{Institutional funding regimes, impact and knowledge exchange}

Right from the formation, in the UK, of the Cambridge Institute of Criminology and the Home Office Research Unit, the ways in which criminological research has been institutionally supported and funded has drawn a critical eye (Garland 2002; Martin 1988). Where funding becomes an issue, the priorities and focus of the funders plays an important role in shaping a priori assumptions about what the problems of the day are, the preferred methods for investigating them, and the main channels through which research is disseminated. They might be said to play a key, even a defining, role in determining what the contours of a discipline is, although in criminology the support of independent universities, and criminology's ongoing expansion as a discipline within them, has historically ensured that funders have enjoyed no such monopoly. Two relatively recent and interrelated developments in the institutional support and funding of criminological research invite consideration of the extent to which we can take for granted the independence of universities, or at least treat universities as places where researchers are entirely free to develop their own agendas. These include the aforementioned 'impact' agenda (in the UK and Australia) and a growing emphasis on 'knowledge exchange'.

In the UK at least, research impact is defined and promoted through nationally organised and compulsory assessment of research activity (most recently in the 2014 Research Excellence Framework, or REF) and it will be incorporated into the Excellence in Research for Australia 
evaluation in 2018. Such benchmarking exercises are used, along with assessments of the quality of research work in general, to determine levels of research funding that academic departments in universities receive, meaning that impact represents an important determinant of the very viability of these departments. Impact in the context of the 2014 UK REF was defined as leading to worthwhile effects on policies and practices in the wider social world. Impact case studies required individuals to demonstrate how their academic work underpinned documentable change. Of course, there remains an element of debate and contestation about the impact agenda and the extent to which its requirements are in fact feasible aspirations for researchers (see, Stella 2014), or whether they demand uncomfortable over-claiming and time scales. Impact therefore represents an important theme for a number of the contributors featured in this volume. For example, Elaine Fishwick's chapter notes that real and positive change can be achieved through research but suggests the paths of this are so unpredictable and circuitous that complexity theory is necessary for analysing them. Similarly, Lesley McAra's chapter argues that pathways to impact are cultivated and navigated over years and decades, time frames which are less amenable to the rapid documentation and measurement sought by universities to evidence their institutional success.

Related to the impact agenda is a growing emphasis on knowledge exchange, a concept that we do not wish to discredit but rather subject to analytical scrutiny. Knowledge exchange came late to criminology, being much more developed in medicine and nursing for example, and underpins the evidence-based policy and practice (EBPP) agendas, also representing a field of research in its own right it. Earlier variants tended to assume that research was a kind of commodity to be packaged and disseminated for unidirectional transfer to those for whom it would be useful. This simple understanding of how research knowledge might come to influence policy or practice was quickly challenged with more nuanced understandings of the complexities and partiality of the process emerging (Henry and Mackenzie 2012; Nutley, Walter and Davies 2007). The evolution of terminology from 'knowledge transfer' to 'knowledge exchange' attempted to reflect the ideal, if not always the reality, that practice should also be influencing research. 'Knowledge exchange' often is treated as a universally positive value and practice, and we note that it more properly refers to particular developments (such as EBPP as noted) and should be analysed more in terms as a movement, with a particular history and set of actors and forces in the same way as we might do with 'what works'. This is not to suggest that sharing knowledge is not beneficial to research or those that it affects or is based on, but that it has come to take on a particular set of meanings and modes of documentation. This bears directly on the next point. 
Collaborative research associations between universities, practitioners and policy makers Undoubtedly related to the particular understanding of knowledge exchange and impact as salient for 'research users' has been the growth of formalised collaborative associations between universities, practitioners and policy makers whereby longer term relationships and more direct collaboration on the research process are envisaged between them. Perhaps the best known in UK criminology is University College London's Jill Dando Institute of Security and Crime Science which, as well as including government as a partner, also seeks to involve criminal justice organisations and the commercial sector. Bilel Benbouzid's chapter in this volume presents the background debates over measuring victimisation that played a tangential role in the formation of this institute and serves to highlight the need for criminologists to study researchers as well as their research in order to make sense of such core issues in criminology. More recently the N8 Research Partnership in England has established a Policing Research network that involves eight university collaborators, government, Police and Crime Commissioners, police services, and partner organisations with relevant interests. Indeed, the editors of this collection have affiliations with similar enterprises in Scotland, including the Scottish Centre for Crime and Justice Research, a collaboration between the Scottish Government, the Scottish Higher Education Funding Council and four Scottish Universities; and the Scottish Institute for Policing Research, a collaboration between Police Scotland, the Scottish Police Authority and 13 Scottish Universities. Other collaborations have emerged or are emerging around the world including the Centre for Evidence-Based Policy in the US and the now defunct Centre for Excellence in Policing and Security in Australia. In many northern European countries (Norway, the Netherlands and Finland, for example) police colleges for the education and professional development of police officers have university status and are staffed by research-active academics, in contrast to the approach in the UK documented by Wood and Williams in this volume whereby academics contribute to police education in a more piecemeal fashion, here with ambition to foster reflexive dispositions within police practitioners. Like funding regimes, these institutional reconfigurations of the places within which research gets done have the potential to profoundly shape criminology and criminal justice for the better (e.g. by supporting more appreciative, engaged, sensitive to practice) or for the worse (e.g. by contributing to less independent, critical and theoretically sophisticated forms of scholarship; or, by imposing 'Northern' understandings of good research and policy onto 'Southern' subalterns, see Blaustein in this volume). The global dimensions and implications of 'collaboration' should not be overlooked as potential sites of critical inquiry: one of the editors of this book, recently returned 
from a trip to Hong Kong with the aim of negotiating university-to-university partnerships, was struck by the frequency of 'global branding' as part of the language of exchange as well as standards of quality (with UK academics hired as consultants to provide REF like reviews of departments in Asian universities, for example).

Changes to the institutional landscape of criminology thus span a wide and evolving range of developments, from criminology being a niche interest conducted in support of criminal court and prison processes (Garland 2002), to the establishment of specialist sites of criminological expertise as in the aforementioned Cambridge Institute of Criminology and the Home Office Research Unit (Martin 1988) (or in the work of Chicago School scholars, to give a US example), to the expansion of criminology within the (increasingly globalised) university sector, to the formation of statutory partnership arrangements (Henry 2012). It has long been recognised that where criminology gets done and under what institutional arrangements shapes its character, its relationship to power, and the problems and challenges to which it directs its gaze.

In the present volume both Alistair Henry and Karen Lumsden pay particular attention to the challenges and possibilities of academic-practitioner collaboration. Henry focuses on the potential (and limitations) for such institutional arrangements to contribute to the cultivation of reflexivity towards the research process amongst practitioners themselves. Lumsden interrogates her experiences of 'doing' reflexivity within this kind of setting, paying particular attention to the 'public engagement/public criminology' dimensions of such endeavours (see also, Loader and Sparks 2011).

Summing up, the current context of criminological and criminal justice research thus far described is complicated, characterised by reconfigured zones of political contestation (more global phenomena on the fringes of traditional criminology), new fields of inquiry (policy making itself), and an emergent institutional landscape of resourcing, assessment and collaboration. Accordingly, we argue that a reflexive disposition is likely to assist in the negotiation of this terrain, but before elaborating on this, it is necessary to consider how the concept of reflexivity is commonly understood within the social sciences by accounting for its sociological origins.

\section{Reflexivity: Some starting points}


Reflexivity in social science research involves researchers recognising the fact that their insights about social worlds and processes (as socially constructed, and mediated by tensions and intersections between agency and structure) also apply to themselves, the social worlds of the academy, and to their own work (see Alvesson and Skoldberg 2009). As such, it is a critique of the myth of positive science and its claims to objectivity and autonomy. According to this myth, social science is done to the world, rather than constructed through and negotiated with it. Reflexive insight challenges truth claims and sees research as interpreting the world through collaboration with it, collaboration that inevitably also changes the world (Law and Urry 2004). Hence, it is something to be taken seriously, particularly in the criminal justice field where state power is exercised in its most extreme forms and where research contributes so substantially to the social construction and definition of the very 'problems' to which it purports to attend. These understandings have come to influence the study of reflexive methodologies in the context of criminological research (see Lumsden and Winter 2014) as well as the discussions of how criminal justice research intersects with policy and practice which feature in this volume. This warrants a brief review of their historical development in the discipline of sociology, specifically in relation to influential work of Alvin Gouldner and Pierre Bourdieu, both of whom are referenced by a number of the contributors to this volume.

Calls for a 'reflexive sociology', that is, a mode of sociological inquiry that seeks to account for how researchers influence and are influenced by the production of scientific and cultural knowledge, can be traced back to the work of the late Alvin Gouldner (1970). Knowledge, according to Gouldner (1970), consists of both 'information' and 'awareness'. Whereas Gouldner believed that positivists have a tendency to reduce their conception of knowledge to the former, his reflexive sociology posits that 'the inquiring subject and the studied object are seen not only as mutually interrelated but also as mutually constituted' (Gouldner 1970: 493). It is therefore the social scientist's awareness of their relationship to the object of their study and of the fact that this relationship is a product of both their personal and professional circumstances which prompts Gouldner (1970: 491) to characterise reflexive sociology as a 'moral sociology' rather than one which purports to be 'value-free' (Id.). Indeed, the values of social scientists and the disciplinary and institutional cultures which they inhabit are deeply embedded within information with the effect that information cannot be described as 'neutral' (Gouldner 1970: 494).

As a 'moral' enterprise, reflexive sociology can be described as embodying two key transformative dimensions: self-transformation and social transformation. Self-transformation is 
linked with the pursuit of and revelation of self-awareness. It is the acknowledgement that the social scientist 'cannot know others unless he [sic] also knows his intentions toward and his effects upon them; he cannot know others without knowing himself, his place in the world, and the forces - in society and in himself - to which he is subjected' (Gouldner 1970: 497). Social transformation refers to the wider field of knowledge production, and accounts for altering definitions of what constitutes valid knowledge, the purposes for which it is sought, and perhaps the means by which it is utilised. For Gouldner, this meant contesting the hegemonic tendencies of Western sociology that he argued were guided largely by positivist aspirations of controlling the social world through the disembodied production of objective knowledge. Gouldner (1970: 504) thereby positions the reflexive sociologist as a partisan, that is, a political being who embraces reflexive sociology as a 'work ethic' that 'affirms the creative potential of the individual scholar'.

Influential in a formative sense with respect to the subsequent popularisation of critical and reflexive approaches to sociology and criminology (see for example, Taylor, Walton and Young 1973), Gouldner's work has also been the subject of criticism within the discipline of sociology. Notably, Hammersley (1999) describes Gouldner's calls for reflexive sociology as a form of 'moral gerrymandering', criticising those who advocate a 'value-free' sociology yet presenting his own prescription for reflexive sociology as 'embodying universal human values, and therefore as not in need of sociological explanation' (Hammersley 1999: para. 2.3). In other words, Gouldner is argued by Hammersley (1999: para. 2.3) to 'present himself as operating in the realm of freedom' while simultaneously reducing the actions and mentalities of those he challenges to functions of cultural, institutional, structural and ideological influences and constraints. Hammersley questions whether sociology as a discipline has, or indeed should have, a privileged role in generating knowledge that dictates social action. Rather, he suggests that 'social action involves contexted processes of interpretation... [which] rely on diverse forms of knowledge... rather than being the 'application' of a body of general knowledge or even of a method' (Hammersley 1999: para. 3.7). On the basis of these critiques, Hammersley (1999: para. 4.1) argues against the practice of formulating 'grand conceptions of sociology's roles' adding that 'reflexivity cannot provide the basis for specifying the mission or the method of sociology'. Accordingly, his contention is that sociological analysis should limit itself to comparatively 'modest' descriptive and explanatory aims and take 'no account of whether we believe what we are studying is good or bad' (Hammersley 1999: para. 4.5). 
The Gouldner and Hammersley debate offers one useful springboard for thinking through reflexivity. Rather than seeing this as presenting a binary choice between different versions, we see an evolving understanding of how the researcher begins to account for herself and understand her role in a field of study. These themes arise as well in feminist epistemologies which similarly challenge the ideas of value-free knowledge and objectivity. Echoing Gouldner, a feminist reflexive stance acknowledges the researcher's position as 'normative and interested' (Cuthbert forthcoming: 2, citing Marshall 2008: 688); at the same time it encourages vigilance of the risks of ideological imperialism and universalism, concerns raised by Hammersley. Indeed feminist (and queer) theory are under used resources in criminology, often limited (ironically and mistakenly) to areas of research cordoned off as 'feminist' and typically limited to explicit studies of gender. Cuthbert's (forthcoming) discussion of feminist epistemology and methods establishes these as having long adopted positions that reflexive criminological work is only now beginning to engage. This includes the recognition that knowledge is always situated (Haraway 1988); that critical research should 'account for the conditions of its own production' (Stanley 1990: 13); and that researchers should be willing to open themselves up to their participants (Cuthbert, forthcoming, citing Reinharz 1992). ${ }^{\mathrm{i}}$

Pierre Bourdieu's work also has proven influential in terms of shifting the gaze of Western sociologists inward, that is, by prompting them to consider their status as 'cultural producers of knowledge'. Like Gouldner, Bourdieu advocated a 'sociology of sociology' (quoting Bourdieu in Wacquant 1989: 33) which actively encouraged its academic practitioners to engage in 'selfanalysis' by considering their epistemological orientation and discursive influences in relation to their positioning within particular fields of knowledge production. It is Bourdieu's emphasis on locating oneself within a field as opposed to a particular profession or institutional or structural configuration that distinguishes his call for reflexive sociology from that of Gouldner. This distinction is important because it recognises that one's discipline and indeed the higher education sector constitute structuring mechanisms in their own right (again, see Stella 2014; Moutnz et al. 2015). For Bourdieu's reflexive sociology then, the boundaries of the field of knowledge production appeared to coincide with the boundaries of the university as the social institution ascribed this unique societal function.

As noted previously however, the university today finds itself continuously prompted to reassert its value as a public good worthy of public expenditure. It must do so by demonstrating its ability to generate research and pedagogical practice of relevance to different 'users' spanning the 
public, private and third sectors. Bourdieu's vocabulary for understanding this reflexive praxis remains especially relevant then because it can accommodate a plurality of knowledge producers representing different institutional positions. Furthermore, against the backdrop of impact, knowledge exchange and academic-practitioner collaboration described at the beginning of this chapter, reflexive sociology establishes the foundations of an important ethos for recursively moderating one's contributions to the production of knowledge as well as for regulating the manner by which such knowledge is disseminated and adopted as a result of our contact with empowered spaces or positions in these fields.

\section{Reflexive criminology?}

Reflexivity has very much arrived as a dimension of social-scientific thinking and practice, even though it took a little longer for the concept to gain a foothold within criminology, at least explicitly. The chapters that follow cumulatively explore, from varying perspectives, the work that criminologists do and the conditions under which they do it, the nature of the research process and the institutions which shape it, for better or worse. We believe that the chapters featured in this volume represent timely and important contributions to an ongoing dialogue about the purpose and value of criminological research but we acknowledge that these issues have long been focal points for critical criminologists who take issue with the collusive, repressive and anti-intellectual origins of the discipline (see for example Heidensohn 1968; Cohen 1988).

We note however that one effect of the emergence of such critical perspectives has been to discourage exploration of areas and involvement with actors perceived to be the source of oppressive and anti-intellectual impulses in criminology. So criminologists study drug users and drug dealers but not civil servants working on harm reduction strategies. Co-production is enthusiastically pursued with young people but not with statisticians. Studying and working with practitioners, and particularly policy makers, remain, despite the impact agenda, ingredients of a spoiled identity for the criminologist. The contributors to this volume go against this grain. Each has spent considerable time studying, working with, and even trying to change, crime and justice policy and practice through research. Their collective contribution lies in illuminating the ways in which criminological research intersects with, constituting and being constituted by, the fields of criminal justice policy and practice that it studies. 
We argue that reflexivity reveals much about the complex, sometimes messy, reality of the research process, allowing for more credible, transparent, and modest engagements across research, policy and practice. In this section we discuss the key points and values of reflexivity for criminal justice researchers, attempting to show how such an orientation in social research can widen and deepen our understanding of the world. However, we have no intention of promoting a 'reflexive criminology' uncritically. We recognise that there are risks of reflexivity as well as particular pathologies - including of navel gazing - and discuss these as well. The aim of this concluding substantive section is to draw together all of these strands towards a clearer sense of how criminologists adopt and might develop reflexive approaches, leaving the rest of the chapters in the book to show how different scholars are 'doing' reflexivity rather than simply 'being' reflexive (Mauthner and Doucet, 2003).

An important insight of the reflexivity literature is that researchers are complex persons who are themselves, in all this complexity, part of the research process, whether they like to acknowledge it or not. Biographical details of the researcher that might be seen to shape or frame their work from their choices of topics and questions, to methodological preferences and skills, to how they interpret the worlds they study, and to how they themselves are interpreted by people in that world - are infinite. However, they have generally included basic demographic characteristics of the researcher (age, race, gender, class) and more particular aspects of their personal lives and histories (whether a parent, a survivor of trauma, a victim of crime or an ex-offender, for example). The choice of discipline, methods, and sub-fields will have been guided more or less consciously by this biography and related/subsequent preferences (personal, political and professional). Many of the contributors to this volume have therefore decided to incorporate autobiographical details into their reflexive discussions of the methodological and practical challenges and prospects inherent to doing research in the sphere of criminal justice. Christopher Harding for example uses his chapter in this volume to provide an auto-biographical discussion of the role that researchers play in constituting and validating narrative constructions of their 'outlaw' subjects by drawing on his own biography and history of researching cartels.

In short, the researcher as a human being is as much of a social construct as any social world or practice that they might hope to study. Scientific rationality and method may allow certain distance and rigor but it does not separate researchers from the world or its influence, lending them clear objective independence and claims to the 'truth'. Articulation of and reflexivity around issues of biography and standpoint is therefore also one of the promising dimensions of 
reflexive, credible and modest research. Being reflexive about one's position in relation to a field means making transparent and holding oneself to account for choices right through the process - from picking topics, designing, doing and interpreting the research, and disseminating it. Such a critical disposition exposes research as always already a negotiated, collaborative and political encounter with the world, not a disembodied, technical process done to it. For example, Ruari McBride's contribution to this volume shows his own gradual awareness of how certain terms, which he himself used, came to construct particular identities of people as 'offenders'. If taken seriously this urges researchers to think about their responsibilities - to those that they research, to the potential effects of both the process and the findings, to the implications for policy and practice, and to the integrity of their own scholarship and the discipline within which they work. Reflexivity as recognition of standpoint therefore improves transparency around the position of the researcher in shaping the process, in foregrounding this position and the responsibilities that flow from it. It also has the potential to cultivate a disposition of responsibility towards research participants and potential users. This is, of course, easier said than done, as Kelly Stockdale's contribution shows, exploring the idea that standpoint in relation to research is itself not static, and is in fact often renegotiated within specific encounters and towards different audiences in the research process, attests (and see, Goffman 1959).

Reflexivity also attunes the researcher to the fact that the field is not an objective given, but is emergent through the activities of the actors (including researchers) who animate it, and responsive to the research process itself (Bourdieu and Wacquant 1992). It gives emphasis to the idea that the researcher may not know in advance the important questions to be explored, and that it is through appreciation of the local contexts of a field of research and how it is understood by actors within it that they might emerge. This is well understood within reflexive approaches to fieldwork - including much ethnography, and collaborative approaches such as participatory action research or 'critical friend' research where researchers are embedded in and responsive to the worlds that they study (Case and Haines 2014). The promise of such approaches is that the researcher becomes curious about elements of the field hitherto unknown, and open to challenging their own a priori assumptions about it through engagement with it.

We note that while reflexive research is often associated with particular methodological approaches, such as ethnography or qualitative work more generally, that this is not a necessary association. Consider the quantitative research of Duiguid and Pawson (1998) evaluating what works in prison education through a quasi-experimental study design and involving a sample of 
over 600 men. They openly describe their orientation to the research as 'hopeful' (Duiguid and Pawson 1998: 473) rather than neutral and disinterested. And, in finding that prison education correlated with reduced recidivism, they qualify this by asking: 'But do we have the patience to give nondirective programs such as education time to do their work? And do we have the humility necessary to accept that we can neither diagnose with precision nor prescribe with surety?' (Duiguid and Pawson 1998: 492). Appreciation of local contexts and possessing a genuine curiosity, modesty and openness to the world and how it works are values that can be expressed in and enhance any research regardless of method (see also Blaustein 2014: 311). Reflexivity, in other words, is a perspective rather than a (prescription of) method (and see Reinharz 1992).

Reflexivity thus conceived entails respect for participants and users of research as active collaborators in the process. Of course, they may not be collaborators who share the researcher's understanding of research or their particular disciplinary frames of reference for interrogating the world. But instead of relegating such differences to being the voices of an unenlightened 'other' a reflexive disposition encourages engagement with and deliberation around them as potentially productive elements in the research process. It encourages taking such different perspectives on more explicitly and not reifying the researcher's voice above all others. This is absolutely not to suggest that a reflexive researcher would not challenge other perspectives including those of the powerful (in fact we very much view this as a responsibility). Rather, a respectful and diplomatic acknowledgement of other perspectives on research is a promising starting point for cultivating an understanding of research and the process of doing research, more a means for prompting informed deliberation about criminal justice problems, and less as instrumental answers to them. Indeed Alistair Henry's chapter suggests deliberation is a more promising long-term aspiration for academic-practitioner collaborations with the police than instrumental goals that target immediate and functional outcomes.

An important component of research diplomacy is modesty and humility about both our skills and status as 'experts', 'scientists' and 'researchers' and about what our research accounts are. Social scientists and bodies of research evidence do not necessarily have 'the answers', or 'the only answers', and a reflexive disposition should remind us of that. To this effect, Jarrett Blaustein's chapter argues that undertaking ethical criminological research 'abroad' necessitates a continuous recognition of the identity that may be conferred upon even an inexperienced researcher as an expert, and the structural asymmetries that both motivate and flow from this. 
This work along with Andrew Jefferson's chapter also raises the problem of the 'other' in a global sense, arguing that reflexivity arises on a different scale where those researchers from the 'developed' North travel and 'share expertise' with those in the 'developing' South.

Embracing complexity and resisting pressures to reduce our findings to appealing and digestible narratives (pressures that we associate, at least in part, with the continued development of a performance management culture in the higher education sector) is also an important element of doing criminology reflexively. This implies that individual pieces of research, and certainly bodies of research, often have complex, partial, and sometimes contradictory or unwelcome messages to convey. These messages are not easily collapsed into the sound bites that research users might be looking for. Rather than trying to provide these sound bites with the aim of securing 'impact' for particular pieces of research, a reflexive disposition encourages caution around this, a caution all the more profound because researchers do enjoy a privileged status and their accounts can play important roles in validating practice or constructing social problems. A more credible dialogue around research is one that is diplomatic in the face of alternative perspectives, and modest about the claims of research to having the 'right answer'. As with a diplomatic disposition, a more modest reflexive disposition would be one that saw both the engagement and collaboration around doing research and the dissemination of research findings and outputs as more about the cultivation of informed deliberation about criminal justice policy and practice, where research is but one kind of evidence. Indeed, a key theme of Lesley McAra's chapter is to question the extent to which researchers have power over the pathways to impact (or not) that their work takes. Her chapter practices humility, even when writing about a research programme that came to have substantial impact on national policy; it reminds us to be careful of what we wish for.

While we recognise the merits of collaborative and diplomatic approaches to undertaking research reflexively with criminal justice policy makers and practitioners, we recognise that sensitivities to the researched and to research audiences are not alternatives to critical research. Rather, we argue that reflexive approaches are promising precisely because they can foster more credible critique through the dispositions just discussed. The credibility stems from the appreciation of policy and practice worlds and contexts, and the modest realism about the claims to be made about the status and claims of research that are implied by reflexive research. However, reflexive research, in emphasising the layers of interpretation at the heart of the process, also does not see research as the simple holding up of a mirror to the world through which it records and in so doing validates its 'reality'. The opposite is very much the case. 
Attentiveness to the lived and negotiated contexts of social worlds and the complex and contested realities within them is to look beneath their surface, to differentiate between what people say and what they do, and to view critically what current practice or experience is, its rationale and meaning for those involved and its fit with wider social expectations. Graham Ellison's chapter gives a powerful account of his experience conducting and disseminating research about sex work practices in Northern Ireland. He is quite open in sharing the personal fallout for himself of intervening in such a politically and morally contested domain, and provocatively makes an argument about the politics of evidence and how research is used, ignored and vilified as part of this. Criminal justice processes have the capacity to exclude, label and coerce and Ellison's work displays how policy processes do as well. Ruari McBride's chapter makes this point as well, and he shows with some poignancy how processes of exclusion might themselves look and feel benign. A reflexive reading of both these chapters renders them as studies in how researchers themselves produce the fields they study, and can become complicit in certain disheartening and disempowering practices (of policy, practice and research) without or despite realising this.

Conducting research on the powerful remains a marginal interest in criminology, and research 'with' the powerful even more so. It is our view that conducting research 'with' the powerful is compatible with a reflexive understanding of the coproduction of knowledge as long as the researcher retains their capacity to uncover and offer challenge. That capacity, or assumptions about it, often relate to the actual and perceived independence of the researcher in relation to their powerful collaborator, a theme that animates many of the contributions to this volume. At the same time it offers new opportunities for and contexts of research. Access that exposes the fine grained dynamics of power that shape practices 'on the street' is just as important and comes with its own particular challenges when the focus is practice 'in the suites' of the powerful. Harry Annison's chapter reveals that civil servants who were involved in the drafting of a profoundly draconian sentencing law were thoughtful, ambivalent, professional and open. Access to these standpoints is crucial for understanding the development and implementation (and possibly reform or repeal) of policy and was achieved here through a collective enterprise between researcher and researched.

Keeping to our promise not to promote reflexivity uncritically, we note some particular risks and pathologies of the reflexive practices we have just touted. A posture of humility and recognition of relative power differences might lead to passiveness, an unwillingness to develop bold claims 
or to intervene. Rejection of a positivistic and singular notion of the truth undermines all claims, levelling research with just one more opinion about the world. If every actor's perspective matters, what right does the researcher have to evaluate and criticise any particular one? Acknowledgement of the researcher's biography and standpoint presents its own set of concerns. Not least of these is solipsistic navel gazing, where considerations of self in the research process overshadow attentiveness to the field, its complexity, and the fact that some things will not be visible through a particular standpoint's gaze. Moreover, the recognition of standpoint may establish new hierarchies of research power and legitimacy. Here the researcher becomes the source of validation of his or her own accounts and arguments, one's biographical 'bias' reified as qualification to speak, and authenticity replacing but having the same imperialistic tendencies as 'neutrality'. This can lead to positions just as entrenched and as ideological as those based upon competing claims of positivist method and epistemology. Another concern in focusing on biographical reflexivity is to overstate the power of and over focus on the researcher's own intentions and contribution and how it is being used. The biographical lens obscures the wider conditions of research, that we have taken care to point out throughout the discussion, involving a knowledge and political economy beyond the control of any individual (Rappert 1999). We might also question the extent to which we are even fully aware of and in control of our own research intentions and contribution, as wider forces undergird the conditions in which these are formed.

Because we conceive of reflexivity as an orientation to and practice of research, and to the world, that is consonant with post-positivist and feminist epistemologies, we do not deny in blanket terms or seek to refute these concerns. We accept these and would aim to resolve and mitigate them through the strategies that we describe earlier in the discussion as the beneficial features of reflexivity: open-mindedness, transparency and modesty. We need to accept that working 'reflexively' may blind us to forms of bias in the same way feminists and critical race scholars have challenged and exposed ostensibly neutral legal and scientific language as deeply raced and sexed. We need to attend to the language we use. For example, the term 'neoliberalism' appears in a number of the chapters, and this might open up a debate about how empirically clear and critically examined this concept is in particular usages. Standpoints are included as core elements in many of the chapters, and the reader may decide for herself whether this is harnessed effectively to display the nature and course of research or whether particular voices and views are therefore silenced. Many of the chapters reflect on or explicitly describe working relationships between researchers and practitioners or policy makers. The telling of these stories should offer 
enough detail to gain a sense of whether critical distance was maintained and insights were achieved. A reflexive turn does not do away with concepts of research integrity or rigour, but seeks to unpack the ways these are socially, and politically, constructed. Where positivist scientific methods measures its results through the minimisation or even elimination of bias, as one example, a reflexive perspective demands the clarification of the biases that are part of all research processes.

In gathering these diverse contributions together in this volume we are 'doing' one kind of reflexivity, which is to show the many ways people are engaging the concept in their own work. That is, we would not wish to promote the idea that there is one way of getting reflexivity 'right'; reflexivity cannot be a universalistic, self-satisfied and untouchable notion. A plurality of approaches, which broadly share and practice the values we have discussed above, are the broad tent in which many might gather. We believe the chapters in this volume showcase deeply interesting and important explorations of the questions, situations and relationships that feature in contemporary criminology and criminal justice.

In concluding this introduction, we would like to note some themes and features of the chapters which can develop our thinking and practice of reflexivity particularly in the context of criminology. Collectively these raise the questions and issues of the kind of conversation we would like to stimulate. First, is the range of ways reflexivity is defined and harnessed in individual chapters, with the authors herein employing the term reflexivity in multiple, multilayered and even, across chapters, potentially competing ways. A number of chapters offer useful typologies and extensive reviews of the concept as it has emerged in the social sciences. For some, it is tied to the idea of reflective practice and research (Stockdale), aimed at supporting reflective practitioners (Wood and Williams) organisations (Jefferson) and relationships (Henry). This work treats researchers as practitioners of a kind as well, which enables the role of the researcher in policy and practice development to become part of the core object of study. Other chapters take reflexivity as an opportunity to grapple directly and critically with the politics of knowledge and power in criminal justice (McBride) as well as (Ellison) policy processes. Sometimes questions of politics require attention to mundane, background issues of a technical nature, like the organisation of a statistical category (Armstrong and Lam) or the modelling disagreements of two criminological camps (Benbouzid). Reflexivity, here, invites attention to the details of practices that do not on their face appear political. Other contributors practice reflexivity in detailing the affective dynamics and consequences (Bosworth and Kellezi, Fishwick) 
of the often tough, and complex, research and policy environments of criminological researchers. Reflexivity is also put to excellent use 'studying up', making visible the people (Annison) and the shifting power dynamics in research on powerful organisations (Lumsden), or the ethics and possibilities of studying 'over there' (Blaustein). Finally, reflexivity, alternately, offers a channel for the biographical, where the researcher's own narrative is paired with the trajectory of a research project (Harding).

In addition to the many ways reflexivity is being defined and practiced, a second area of interest are the kinds and range of theoretical and methodological resources drawn on by individual authors. While many refer to specific debates and elaborations of reflexivity in the work of Bourdieu, Gouldner, Hammersley, Burawoy, or long standing influences in criminology such as Foucault, Bauman and Goffman, additional thinkers and fields include Paulo Friere, complexity theory, Donald Schön, Interpretive Policy Analysis, Science and Technology Studies, John Dryzek and more. Reflexivity has meant casting the net wider to include not only subjects that have been at the fringe of criminology, such as policy makers and university research structures; it has also meant looking to other disciplines for tools and inspiration. Contributors to this volume move well beyond criminology's favoured fields of sociology, law, social work and psychology to draw on work in education, politics, anthropology, public administration and more. Through notions of reflexivity, the scholars in this collection are introducing the language of emancipation, social justice, solidarity and democratic deliberation into the conversation. This has the potential to increase the ambition and critical scrutiny of research impact agendas, allowing for critical debates to emerge about supporting research that genuinely promotes positive change in the world.

\section{A brief note about the structure of this volume}

The book is organised into three crosscutting themes that loosely correspond to the three parts of this book. These allow the reader to focus on a particular major theme in approaching the volume, though all chapters overlap in these themes to some extent. The parts are as follows:

1. Reflexive Approaches to Criminal Justice Policy Research: Each of these chapters has at its heart a specific policy development that serves as an opportunity to conduct a detailed, theory-rich approach that makes sense of them. They include Imprisonment for Public Protection (IPP) sentences in England and Wales (Annison); juvenile justice policy in New South Wales, Australia (Fishwick); the 'mentally disordered offender' (MDO) category in Northern 
Ireland (McBride), reform of short prison sentences in Scotland (Armstrong and Lam); and statistically modelling victimisation in England and Wales in the 1990s (Benbouzid).

2. Collaboration and Knowledge Exchange in Practice: The chapters in this section focus on examples of engagement in different contexts between researchers, practitioners and policy makers. They thoroughly address the challenges and potential of collaboration, sometimes specifically in the context of knowledge exchange and impact, but also more generally for conducting research. They range in area and jurisdiction to include youth justice policy in Scotland (McAra); policing-academic collaborations in Scotland (Henry) and England (Lumsden); academic involvement in professional education of police in England (Wood and Williams); and working with Home Office and Immigration Removal Centre (IRC) staff to research the experiences of detained people (Bosworth and Kellezi).

3. Positionality, Power and the Reflexive Imperative: This section comprises chapters that highlight, among other things, lessons and insights of researcher positionality. These include absentpresences in biographies of researcher and researched in studying anti-cartel regulation across Europe (Harding); the blurring of professional and ad hominem critique in passing a zero tolerance policy on sex work in Northern Ireland (Ellison); navigating insider-outsider status in researching a police force in northern England (Stockdale); reflecting on tensions in the mission versus sustainability issues of an anti-torture organisation based in Denmark (Jefferson); and using the experience of being a 'Northern' researcher in the global 'South' to reflect on the ethics of engagement and the possibility of a civic criminology (Blaustein).

\section{References}

Alvesson, M. and Skoldberg, K. (2009) Reflexive Methodology: New Vistas for Qualitative Research (2nd edn), London: Sage.

Annison, H. (2015) Dangerous Politics: Risk, Political Vulnerability, and Penal Policy, Oxford: Oxford University Press.

Armstrong, S. (2010) 'Prison Prisms: Policy's Objects in Scottish Penal Reform', Conference paper, Interpretive Policy Association, Grenoble, France (July). URL (accessed 14 May 2016): http://www.researchcatalogue.esrc.ac.uk/grants/RES-000-22-2881/read. 
Australian Research Council (ARC) (2016) 'Science and Research Priorities', Website. URL (accessed 14 May 2016): http://www.arc.gov.au/science-research-priorities.

Blaustein, J. (2014), 'Reflexivity and Participatory Police Ethnography: Situating the Self in a Transnational Criminology of Harm Production'. In K. Lumsden and A. Winter. (eds.) Reflexivity in Criminological Research: Experiences with the Powerful and the Powerless, Basingstoke: Palgrave Macmillan: 301-312.

Blaustein, J. (2015) Speaking Truths to Power: Policy Ethnography and Police Reform in Bosnia and Herzegovina, Oxford: Oxford University Press.

Bosworth, M. and Hoyle, C. (2011) What is Criminology?, Oxford: Oxford University Press.

Bourdieu, P. and Wacquant, L. (1992) Invitation to a Reflexive Sociology, Chicago: The University of Chicago Press.

Brown, D., Cuneen, C., Schwartz, M., Stubbs, J. and Young, C. (2015) Justice Reinvestment: Winding Back Imprisonment, Basingstoke: Palgrave.

Case, S. and Haines, K. (2014) 'Reflective Friend Research: The Relational Aspects of Social Theory'. In K. Lumsden and A. Winter (eds), Reflexivity in Criminological Research: Experiences with the Powerful and the Powerless, Basingstoke: Palgrave Macmillan: 58-74.

Cohen, S. (1988) Against Criminology, London: Transaction Publishers.

Crawford, A. (1998) Crime Prevention and Community Safety: Politics, Policies and Practices, London and New York: Longman.

Cuthbert, K. (forthcoming) Exploring the gendered experiences of those who do not feel sexual attraction, and those who choose not to be sexually active, Doctoral dissertation, University of Glasgow, manuscript in file with the editors.

Downes, D. and Morgan, R. (2012) 'Overtaking on the Left? The Politics of Law and Order in the "Big Society". In M. Maguire, R. Morgan and R. Reiner (eds.) The Oxford Handbook of Criminology, 5th edn, Oxford: Oxford University Press: 182-205. 
Duguid, S. and Pawson, R. (1998) 'Education, Change, and Transformation: The Prison Experience', Evaluation Review 22(4): 470-495.

Ericson, R.V. and Carriere, K. (1994) 'The Fragmentation of Criminology'. In D. Nelken (ed.) The Futures of Criminology, London: Sage: 89-109.

Foucault, M. (1980) Power/Knowledge: Selected Interviews and Other Writings, 1972-1977, Brighton: Harvester Press.

Garland, D. (1996) 'The Limits of the Sovereign State: Strategies of Crime Control in Contemporary Society', British Journal of Criminology 36(4): 445-471.

Garland, D. (2000) 'The Culture of High Crime Societies: Some Preconditions of Recent Law and Order Policies', British Journal of Criminology 40(3): 347-75.

Garland, D. (2002) 'Of Crimes and Criminals: The Development of Criminology in Britain'. In M. Maguire, R. Morgan and R. Reiner (eds), The Oxford Handbook of Criminology, 3rd edn, Oxford: Oxford University Press: 7-50.

Garland, D. and Sparks, R. (2000) 'Criminology, Social Theory and the Challenge of Our Times'. In D. Garland and R. Sparks (eds.), Criminology and Social Theory, Oxford: Oxford University Press: 1-22.

Goffman, E. (1959) The Presentation of Self in Everyday Life, London: Penguin Books.

Gouldner, A.W. (1970) The Coming Crisis of Western Sociology, London: Heineman Educational Books Ltd.

Hammersley, M. (1999) 'Sociology, What's It For? A Critique of Gouldner', Sociological Research Online 4(3): no page numbers.

Haraway, D. (1988) 'Situated Knowledges: The Science Question in Feminism and the Privilege of Partial Perspective', Feminist Studies 14(3): 575-599. 
Heidensohn, F. (1968) 'The Deviance of Women: A Critique and an Inquiry', The British Journal of Sociology 19(2): 160-175.

Henry, A. (2012) 'Situating Community Safety: Emergent Professional Identities in Communities of Practice', Criminology and Criminal Justice 12(4): 413-431.

Henry, A. and Mackenzie, S. (2012) 'Brokering Communities of Practice: A Model of Knowledge Exchange and Academic-Practitioner Collaboration Developed in the Context of Community Policing', Police Practice and Research 13(4): 315-328.

Hough, M. (2014) 'Confessions of a Recovering “Administrative Criminologist”: Jock Young, Quantitative Research and Policy Research', Crime Media Culture 10(3): 215-226.

Jones, T. and Newburn, T. (2002) 'Policy Convergence and Crime Control in the USA and the UK: Streams of Influence and Levels of Impact', Criminal Justice: The International Journal of Policy and Practice 2(2): 173-203.

Law, J. and Urry, J. (2004) 'Enacting the Social', Economy and Society 33(3): 390-410.

Loader, I. (2006) 'Fall of the "Platonic Guardians”, British Joumal of Criminology 46(4): 561-586.

Loader, I. and Sparks, R. (2011) Public Criminology?, London: Routledge.

Lumsden, K. and Winter, A. (2014) Reflexivity in Criminological Research: Experiences with the Powerful and the Powerless, Basingstoke: Palgrave Macmillan.

Maguire, M. (2012) 'Criminal Statistics and the Construction of Crime'. In M. Maguire, R. Morgan and R. Reiner (eds), The Oxford Handbook of Criminology, 5th edn, Oxford: Oxford University Press: 206-244.

Martin, J.P. (1988) 'The Development of Criminology in Britain, 1948-1960', British Journal of Criminology 28(2): 35-44. 
Mauthner, N. and Doucet, A. (2003) 'Reflexive Accounts and Accounts of Reflexivity in Qualitative Data Analysis', Sociology 37(3): 413-431.

McAra, L. (2005) 'Modelling Penal Transformation', Punishment and Society 7(3): 277-302.

McAra, L. (2016) 'Can Criminologists Change the World? Critical Reflections on the Politics, Performance and Effects of Criminal Justice', British Journal of Criminology, first published online March 11, 2016 doi: 10.1093/bjc/azw015.

Morrison, K. and Sparks, R. (2015) 'Research, Knowledge and Criminal Justice Policy: The Scottish Experience'. In H. Croall, G. Mooney and M. Munro (eds.), Crime, Justice and Society in Scotland, London: Palgrave.

Mountz, A., Bonds, A., Mansfield, B., Loyd, J., Hyndman, J., Walton-Roberts, M., Basu, R., Whitson, R., Hawkins, R., Hamilton, T, Curran, C. (2015) 'For Slow Scholarship: A Feminist Politics of Resistance through Collective Action in the Neoliberal University', ACME: $A n$ International E-Journal for Critical Geographies 14(4, August): 1235-1259. URL (accessed 14 May 2016): http://ojs.unbc.ca/index.php/acme/article/view/1058.

Newburn, T. and Sparks, R. (2004) Criminal Justice and Political Cultures: National and International Dimensions of Crime Control, Cullompton: Willan.

Nutley, S., Walter, I. and Davies, H.T.O. (2007) Understanding Evidence: How Research can Inform Public Services, Bristol: The Polity Press.

Power, M. (1999) The Audit Society: Rituals of Verification, Oxford: Oxford University Press.

Rappert, B. (1999), 'The Uses of Relevance: Thoughts on a Reflexive Sociology', Sociology 33(4): 705-723.

Reinharz, S. with Davidman, L. (1992) Feminist Methods in Social Research, New York and Oxford: Oxford University Press. 
Simon, J. (2007) Governing Through Crime: How the War on Crime Transformed American Democracy and Created a Culture of Fear, Oxford: Oxford University Press.

Souhami, A. (2007) Transforming Youth Justice: Occupational Identity and Cultural Change, Cullompton: Willan.

Stanley, L. (1990) 'Feminist Praxis and the Academic Mode of Production: An Editorial Introduction'. In L Stanley (ed.) Feminist Praxis: Research, Theory and Epistemology in Feminist Sociology, London: Routledge: 3-19.

Stella, F. (2014) 'Engaging with "Impact” Agendas? Reflections on Storytelling as Knowledge Exchange'. In Y. Taylor (ed.) The Entrepreneurial University: Engaging Publics, Intersecting Impact, Basingstoke: Palgrave Macmillan: 105-124.

Taylor, I., Walton, P. and Young, J. (1973) The New Criminology: for a Social Theory of Deviance, London: Routledge and Kegan Paul.

Wacquant, L. (1989) 'For a Socio-Analysis of Intellectuals: On Homo Academicus', Berkeley Journal of Sociology 34: 1-29.

Young J. (1986) ‘The Failure of Criminology: The Need for a Radical Realism'. In R. Matthews and J. Young (eds.) Confronting Crime, London: SAGE Publications.

\section{NOTES}

\footnotetext{
${ }^{\mathrm{i}}$ The references to feminist methodology directly draw on and benefit from Cuthbert (forthcoming), however any error in interpretation and application of this discussion to a criminological subject matter remains entirely with the authors.
} 